\title{
Volatility Spillover Among Asian Developed Stock Markets to Indonesia Stock Market During Pandemic Covid-19
}

\author{
Yunia Panjaitan ${ }^{1}$, Rizky Novel $^{2}$ \\ 1,2Department of Management, Faculty of Economics and Business \\ Atma Jaya Catholic University of Indonesia \\ *Corresponding Author: yunia.panjaitan@atmajaya.ac.id
}

\begin{abstract}
This study aims to analyze the transmissions of volatility spillovers from China, Singapore, South Korea, and Japan stock markets to the Indonesian stock market and prove an asymmetric effect on spillover volatility. The data retrieved from the stock index of each country in the period 2020. The analytical method used is the Exponential GARCH (EGARCH) specification developed by Nelson (1991). The results of data analysis show that there was no spillover of volatility from the stock markets of China, Singapore, South Korea, and Japan to the Indonesian stock market. The data analysis results also showed an asymmetric effect on the spillover of volatility from the stock markets of China, Singapore, South Korea, and Japan to the Indonesian stock market.
\end{abstract}

Keywords: Asymmetric; EGARCH; Volatility Spillover.

\section{INTRODUCTION}

Economic globalization is a phenomenon where there is an increase in economic integration between countries and economic dependence between one country and another. Economic integration can be seen from the space where the passage of goods and capital is no longer limited by the absolute lines of democracy between countries. Economic integration helps countries remove these lines to be boundless, effective, and efficient.

Indonesia, as a developing country, is undoubtedly very dependent on economic integration. In the last few decades, the relationship between Indonesia's economy and global economic integration has been very significant, marked by the growth of international trade. Based on statistical data issued by the Indonesian Investment Coordinating Board (BKPM) Indonesia's export value growth was 9\% from 2015, amounting to US\$150.366,29 million until the end of 2019, amounting to US\$167.683,01 million. Likewise, imports, which experienced a $25 \%$ growth from 2015 amounting to US\$ $142,649.81$ million until the end of 2019, amounting to US\$171,275.74 million Based on asset value data issued by KSEI for the period January 2019 - December 2019, the ownership of 
stock assets scripless on average was dominated by foreign of $52 \%$ compared to ownership local assets $48 \%$. Meanwhile, from data taken from the Investment Coordinating Board (BKPM) of the Republic of Indonesia, investment realization from January 2019 to December 2019 was based on the number of projects undertaken, and the investment value was dominated by four Asian countries, namely Singapore, Japan, South Korea, and China. In the first place, Singapore has 7,020 projects with the highest total investment of U.S. \$ $6,509.6$ million. Followed by Japan, which has 3,835 projects with a total investment of U.S. $\$ 4,310.9$ million. In third place, there is China with a total of 2,130 projects with a total investment of U.S. \$ 4,744.5 million. Finally, there is the country of South Korea which is working on 2,925 projects with a total investment of U.S. \$1,070.2 million.

The emergence of the COVID-19 pandemic in early January made China, Singapore, South Korea, and Japan, which are the largest contributors to investment in Indonesia, experience an economic crisis due to the COVID-19 virus. The Asian continent, which is the epicenter of the spread of the COVID-19 virus, has brought negative shocks to almost all countries. The linkage between the Indonesian stock market and China's stock markets, Singapore, South Korea, and Japan, can lead to spillover volatility. There is also a lot of research on spillover volatility which proves the asymmetric effect between one market and another when occurring spillover volatility. The asymmetric effect is a condition where there are differences in the response of asset returns to positive or negative events and tend to be negative events (bad news), creating a spillover greater volatility than during positive events (Lestano and Sucito, 2010). Saadah (2013) captures a response asymmetric to the spillover volatility between the Singapore stock market and Indonesia, especially during the bearish phase. Lestano and Sucito (2010) also capture the spillover volatility and asymmetric effect from Singapore to the Indonesia stock exchange. Koutmos and Booth (1995) found that there was asymmetrical spillover volatility between the New York, Tokyo, and London exchanges. Research from Tumbelaka (2019) compared 6 GARCH models, which proved that the Exponential-GARCH asymmetry model is the best model to capture the stock market in Indonesia and Malaysia. To detect the spillover volatility, the author used a spillover volatility model constructed from an autoregressive model with a combination of Exponential Generalized Auto Regressive Conditional Heteroskedasticity (EGARCH) asymmetry model.

There is also a lot of research on spillover volatility which proves the asymmetric effect between one market and another when there is spillover volatility. Researchers want to prove whether this volatility spillover still occurred during the Covid-19 pandemic. Therefore, the authors want to see the relationship between the transmission of volatility asymmetrically from Asian stock markets contributing to investment in Indonesia from developed economies (China, Singapore, South Korea, and Japan). And to the volatility of the Indonesian stock market and vice versa, during the pandemic virus outbreak COVID19 from January 1, 2020, to December 31, 2020. This research is expected to provide benefits for investors in managing risk, determining decisions in allocation assets, and diversify their portfolios to achieve optimal portfolios. This research can also assist the local government in dealing with high volatility as a result of negative shocks by making policies or stimulus so that economic stability can always be maintained. Finally, this research is expected to be input and reference for future researchers as a reference or reference. 


\section{HYPOTHESES DEVELOPMENT}

Spillover is a category of contagion which is defined as spillover that is created from interdependence excessive between the economies of various countries. Brooks (2008) defines spillover as the tendency for volatility to change in one market or asset following changes in volatility in other markets. It signifies the rapid movement of information through a sequence of short-term volatility changes through several markets. In general, the volatility of stocks or assets is caused by new information in the market. There is a change in the asset's value and the result of volatility (Hull, 2015). The Spillover volatility is the result of financial market interventions between countries. The term interdependence means that the movement of financial markets in one country can have implications for other countries' financial markets as a form of market integration.

Phenomena Asymmetric can be observed in different but related dynamics of asset prices, i.e.:

(1) The most substantial evidence of asymmetry in price dynamics is asset found in the volatility response to price changes which can be found in the Leverage Effect (Black, 1976; Christie, 1982) and the Volatility Feedback Effect (Campbell and Hentschell, 1992).

(2) There is a mean reversion of prices asset. Empirical studies show that negative changes in stock prices reverse faster than positive changes. Therefore, returns positive generally indicate positive autocorrelation, while returns negative indicate negative autocorrelation (Koutmos, 1998; Nam et al., 2001).

(3) Several empirical studies have shown that the covariance and correlation between returns will increase during market bear and decrease during market bull (Lin et al., 1994; Ang and Bekaert, 2002; Das and Uppal, 2004; Capiello et al., 2006). in the context of the international equity market, this phenomenon is manifested in an asymmetric spillover return and volatility.

According to Huang, C. et al. (2020), the first case of the patient who contracted the COVID-19 virus was identified on December 1, 2019. The announcement of a new virus made many countries take preventive action by closing transportation routes from air, land, and sea and closing trade routes. The Asian continent is the epicenter of the spread of the COVID-19 virus, which brought adverse shocks to almost all countries. Moreover, WrenLewis (2020) claims that the COVID-19 pandemic will significantly impact a country's GDP due to decreased production and decreased consumer demand. Furthermore, the pandemic will exacerbate the situation if banks fail to meet the financing needs of companies due to a sudden drop in demand. This will ultimately lead to the collapse of stock markets around the world. Boon, Haugh, Pain, and Salins (2020) explain that three channels can affect the global economy due to the Covid-19 pandemic, namely factory closings, cuts in the service sector, and disruptions to world supply chains which will lead to a decline in overall supply. Sharma (2020) conducted a study to see the similarities in the impact of the Covid-19 pandemic in five stock markets of developing countries in Asia (Hong Kong, Japan, Russia, Singapore, and South Korea. The research shows that there are similarities in volatility during the Covid-19 period and volatility is more prominent in Singapore compared to the other four countries. Khan, Zhao, Zhang, Yang, Shah, and Jahanger (2020) conducted a study to find out the impact of the COVID-19 pandemic on the stock market. As for the number of countries that have an impact on the affected stock market is 16 countries, and it is certain to have an adverse reaction to all stock market 
indices in the short term and the long term, only the Chinese stock market (SSEC) has managed to rebound in the long term. The results showed a strong relationship between the Indonesian stock market and the Singapore stock market, which causes turmoil in the Singapore stock market, affecting the volatility of returns of the Indonesian stock market. The Spillover volatility also occurs asymmetrically where the transmission of volatility from the Singapore stock market to the Indonesian stock market is stronger if the Singapore stock market experiences a return negative (Panjaitan and Saadah, 2018; Saadah, 2013; Lestano and Sucito, 2010; Sari, Achsani, and Sartono, 2017).

Joshi (2011) researched the volatility spillover in Asian stock markets using the GARCH model. The results showed that there was a bidirectional co-movement between the stock market. Moreover, Joshi found that the volatility spillover within the stock market itself was higher than between the stock markets. Research results from Kibtiyah, Shintia, and Trikartika (2017) found no relationship between the Chinese stock market and the Indonesian stock market. In contrast to the research results by Martin and Yunita (2010), there is a relationship between the Indonesian stock market and the Chinese stock market, which can be seen from the occurrence of volatility spillover, which is only unidirectional. According to $\mathrm{Wu}$ (2005), his research showed spillover volatility between Japan, Singapore, Indonesia, and the Philippines, which left South Korea as a country that did not influence spillover volatility.

Meanwhile, in her research, Miyakohsi (2003) found that the influence of the U.S. can affect the return on Asian stock markets, and the volatility is more influenced by the Japanese market than the United States. There is an adverse effect of volatility from Asia to the Japanese market. Many studies and empirical studies show that spillover volatility occurs asymmetrically, which means that the impact of bad news on asset prices tends to be greater than the impact of good news. Therefore, the researcher describes the hypotheses tested in this study are:

$\mathrm{H}_{1}$ : There is Asymmetric spillover volatility from the Chinese stock market against the Indonesian stock market.

$\mathrm{H}_{2}$ : There is Asymmetric spillover volatility from the Singapore stock market against the Indonesian stock market.

$\mathrm{H}_{3}$ : There is Asymmetric spillover volatility from the South Korean stock market against the Indonesian stock market.

$\mathrm{H}_{4}$ : It occurs asymmetric spillover volatility from the Japanese stock market against the Indonesian stock market.

\section{METHOD, DATA, AND ANALYSIS}

In this study, the author used five variables, i.e., one dependent variable and four independent variables. Furthermore, The dependent variable used is the Indonesian stock price index (JKSE). In contrast, the independent variable uses the closing value of the four countries' stock price index. The five variables will be presented in table 1 . 
Table 1. Symbol and Name of Indices Variables

\begin{tabular}{cccc}
\hline Country & Variable & Symbol & Indices \\
\hline Indonesia & Dependent & IKSE & Takarta Composite Index \\
China & Independent & SSEC & Shanghai Composite Index \\
Singapore & Independent & STI & Strait Times Index \\
South Korea & Independent & KS11 & Korea Composite Index \\
Japan & Independent & N225 & Nikkei 225 \\
\hline
\end{tabular}

The data collected is data from the stock market indexes of Indonesia (JKSE), China (SSEC), Singapore (STI), South Korea (KS11), and Japan (N225) taken from the period January 1, 2020 - December 31, 2020, with a total of 262 observations. There are four prices in the stock index movement, namely, open, high, low, close. To calculate the return of the five-stock market index, the researchers used the closing price (close) stock market index. Thus, the return is formulated using the arithmetic yield formula according to Martin and Yunita (2010), as the following equation (1).

$$
R_{t}=\frac{\left(P_{t}-P_{t-1}\right)}{P_{t-1}}
$$

Where $P_{t}$ is a symbol for closing prices of the stock market index at t-day, and $P_{t-1}$ is a symbol for closing prices of the stock market index at previous $t$-day.

Before applying the EGARCH model to research, financial data must be tested for data normality first. The data normality test aims to determine whether the data under study can be normally distributed or not. According to Winarno (2017: 5.40), the JarqueBera normality test is based on the value of skewness and kurtosis equal to zero, indicating that the data is normally distributed. So that it can be concluded that there are three main requirements for applying ARCH / GARCH model analysis. The first condition is the value of kurtosis $>3$, the second condition is to have a value of skewness $\neq 0$, and the last condition is the Jarque-Berra probability $<a 10 \%$.

After the data normality test, it is necessary to do the ARCH Lagrange Multiplier test which was popularized by Engle (1982). The ARCH-LM test is essential to do before using the ARCH / GARCH model to determine whether variables contain ARCH effects (heteroscedasticity). If the data under study shows an $\mathrm{ARCH}$ effect, the dependent variables in this study will be carried out using the EGARCH method.

This study uses the EGARCH model (Nelson, 1991) because this model can overcome data modeling with non-constant variance and capture the asymmetric and leverage effects of financial markets. Hill, Griffiths, and Lim (2012) state that the EGARCH model is useful for seeing the asymmetry effect in the stock market. When bad news enters the market, asset prices will tend to enter a turbulent phase, volatility increases, but volatility tends to decrease if positive news comes to the market and the market enters a calm phase.

The specification of the EGARCH model in this study uses the equation in Panjaitan and Saadah's (2018) research, which is as following equation (2) and equation (3). 


$$
\begin{gathered}
y_{t}=\mu+u_{t} \quad u_{t} \approx N\left(0, \sigma_{t}^{2}\right) \\
\ln \left(\sigma_{t}^{2}\right)=\omega+\beta \ln \left(\sigma_{t-1}^{2}\right)+\gamma \frac{u_{t-1}}{\sqrt{\sigma_{t-1}^{2}}}+\alpha\left[\frac{\left|u_{t-1}\right|}{\sqrt{\sigma_{t-1}^{2}}}-\sqrt{\frac{2}{\pi}}\right]
\end{gathered}
$$

In this study, the researcher wanted to see the spillover volatility and asymmetric effects from the stock markets of China (SSEC), Singapore (STI), South Korea (KS11), and Japan (N225) to the Indonesian stock market (JKSE). For this reason, a modification is needed to the EGARCH model specification on the mean and variance equation, which becomes equation (4) and equation (5).

$$
\begin{aligned}
& J K S E_{t}=\alpha_{0}+\alpha_{1} S S E C_{t}+\alpha_{2} S T I_{t}+\alpha_{3} K S 11_{t}+\alpha_{4} N 225_{t}+u_{t} \\
& \ln \left(\sigma_{t}^{2}\right)=\omega+\beta \ln \left(\sigma_{t-1}^{2}\right)+\gamma \frac{u_{t-1}}{\sqrt{\sigma_{t-1}^{2}}}+\alpha\left[\frac{\left|u_{t-1}\right|}{\sqrt{\sigma_{t-1}^{2}}}-\sqrt{\frac{2}{\pi}}\right]+\delta_{1} \ln \left(\sigma_{t, S S E C}^{2}\right)+ \\
& \delta_{2} \ln \left(\sigma_{t, S T I}^{2}\right)+\delta_{3} \ln \left(\sigma_{t, K S 11}^{2}\right)+\delta_{4} \ln \left(\sigma_{t, N 225}^{2}\right)
\end{aligned}
$$

In this study, JKSE is the dependent variable of the composite stock price index. Meanwhile, the independent variables consist of SSEC, STI, KS11, and N225.

Parameter $\omega$ is a constant parameter. The parameter $\beta$ (GARCH Coefficient) is a parameter to measure the impact of good or bad news in the previous period on the current volatility return. If the parameter is significant, it indicates the market has a persistent volatility effect. The parameter $\gamma$ (Asymmetric Coefficient) is a parameter to see an asymmetric response to the spillover volatility, so the existence of the effect leverage as an effect is asymmetrically tested with the hypothesis that $\gamma<0$ and the impact are asymmetric if $\gamma \neq 0$. Two parameters $(\gamma+\alpha)$ and $(\gamma-\alpha)$ Describe the response asymmetric of volatility to shocks from good news and bad news. If $(\gamma<0)$ The shock originating from good news will increase the volatility smaller than the shock originating from lousy news with shock the same. The parameter a (ARCH Coefficient) is a parameter to see if the phenomenon exists in volatility clustering.

$\sigma_{t, S S E C}^{2}, \sigma_{t, S T I}^{2}, \sigma_{t, K S 11}^{2}$, and $\sigma_{t, N 225}^{2}$ are the shocks (volatility) that occurred in the stock markets of China, Singapore, South Korea, and Japan.

Parameter $\delta_{1}, \delta_{2}, \delta_{3}, \delta_{4}$ are a parameters that measure the magnitude of the intensity of the spillover volatility from the stock markets of China, Singapore, South Korea, and Japan to the Indonesian stock market.

After processing the data using the EGARCH model, the ARCH-LM test needs to be done again to check for the possibility that the ARCH effect is still present in each of the variables used in the research model.

\section{RESULTS}

This study uses 5 variables, namely the Jakarta Composite Index (JKSE), the Shanghai Composite Index (SSEC), the Strait Times Index (STI), the Korea Composite Index (KS11), the Nikkei 225 (N225). 
Table 2. Data Normality Test

\begin{tabular}{cccccc}
\hline & R_JKSE & R_SSEC & R_STI & R_KS11 & R_N225 \\
\hline Skewness & 0.296246 & -0.866363 & -0.386912 & -0.082889 & 0.368266 \\
Kurtosis & 10.35377 & 10.19194 & 8.875650 & 8.671672 & 7.994910 \\
& & & & & \\
Jarque-Bera & 591.9152 & 595.1481 & 381.9525 & 350.1243 & 277.2212 \\
Probability & 0.000000 & 0.000000 & 0.000000 & 0.000000 & 0.000000 \\
\hline Note: Significance at a $10 \%$ & & & &
\end{tabular}

From table 2. it can be concluded that the results of data processing show that the five countries show skewness $\neq 0$, which means that the data is not normally distributed (asymmetry). Results kurtosis from the five countries $>3$ which means that the data is leptokurtic, stating that the data is otherwise not normal for data distribution has a sharper peak is positive, so the emergence of time-varying volatility, the early symptoms of heteroskedasticity, and the phenomenon of fat-tails. With a significance level of a $10 \%$, the five countries show the Jarque-Bera probability < a $10 \%$ results, which means that the residual data of the return five countries are not normally distributed.

Thus, the descriptive statistical analysis above shows that the data for return the JKSE, SSEC, STI, KS11, and N225 indices are proven to show heteroscedasticity and are not normally distributed so that the ARCH / GARCH model analysis can be applied in this study.

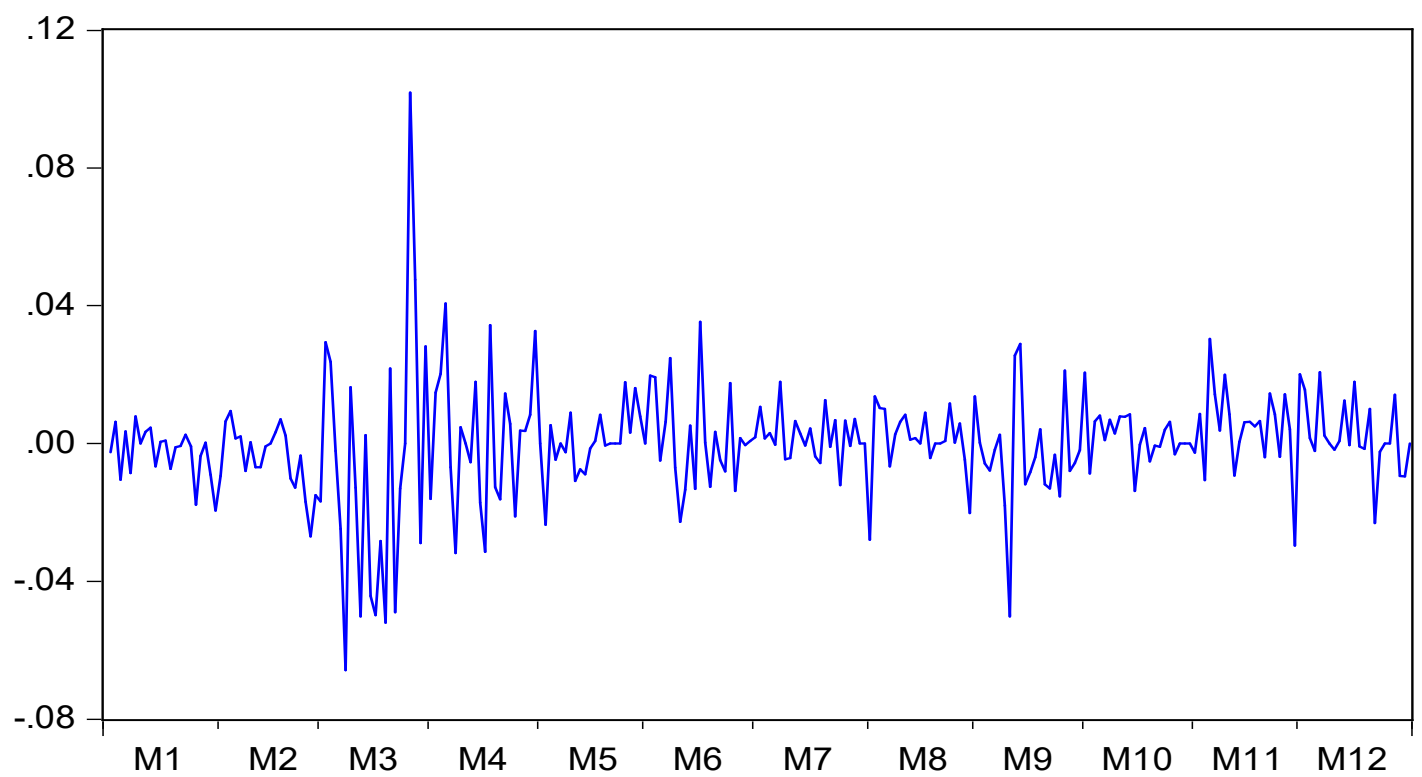

Figure 1. The Movement Data Return of Indonesian Stock Market Index (JKSE) in 2020

In Figure 1, the volatility that occurs in the return of the Indonesian state stock index is not constant. In this figure, it can be analyzed that there is a different volatility movement in each period. There are times when the stock price return index is very volatile, and there are periods where the stock price return index is not very volatile or stable. This indicates the occurrence of the phenomenon volatility clustering, where the volatility that occurs forms clusters. 
Table 3. ARCH Effect: LM-Test

\begin{tabular}{cccc}
\hline F-statistic & 14.47961 & Prob. F(1,62) & 0.0002 \\
Obs*R-squared & 13.81644 & Prob. Chi-Square(1) & 0.0002 \\
\hline
\end{tabular}

Note: Significance at a $10 \%$

Based on table 3. the ARCH LM-Test above shows the Prob value. obs- $\mathrm{R}$ * -squared is 0.0002 , so it is proven that the p-value is < a $10 \%$, then the null hypothesis is rejected, which means that the residual data is proven in heteroscedasticity conditions.

Table 4. provides information on the EGARCH estimation results that can see the spillover volatility and asymmetric effects from the stock markets of China (SSEC), Singapore (STI), South Korea (KS11), and Japan (N225) to the Indonesian stock market (JKSE). The result of parameter GARCH Coefficient ( $\beta$ ), which is 0.223952 with a p-value of $0.0292<a 10 \%$, indicates that parameter GARCH Coefficient $(\beta)$ is positive and significant which means that the impact of news the previous period greatly affects the volatility return current. The result of parameter ARCH Coefficient $(\alpha)$ is 0.921766 with a p-value of $0.0000<\alpha 10 \%$, indicating that the above model has the phenomenon of volatility clustering.

Table 4. EGARCH estimation for volatility spillover from China, Singapore, South Korea, and Japan to Indonesia

\begin{tabular}{|c|c|c|c|c|}
\hline Mean Equation & Coefficient & Std. Error & z-Statistic & Prob. \\
\hline $\mathrm{C}$ & -0.000400 & 0.000661 & -0.604637 & 0.5454 \\
\hline \multicolumn{5}{|l|}{ Variance Equation } \\
\hline Constant $(\omega)$ & -0.871603 & 0.320979 & -2.715451 & 0.0066 \\
\hline GARCH Coefficient $(\beta)$ & 0.223952 & 0.102704 & 2.180556 & 0.0292 \\
\hline Asymmetry Coefficient $(\gamma)$ & -0.167792 & 0.047773 & -3.512291 & 0.0004 \\
\hline ARCH Coefficient (a) & 0.921766 & 0.030782 & 29.94507 & 0.0000 \\
\hline \multicolumn{5}{|l|}{ Variance Equation } \\
\hline SSEC Volatiliy Spillover $\left(\delta_{1}\right)$ & -4.164574 & 4.000479 & -1.041019 & 0.2979 \\
\hline STI Volatiliy Spillover $\left(\delta_{2}\right)$ & -7.287146 & 5.172583 & -1.408802 & 0.1589 \\
\hline KS11 Volatiliy Spillover $\left(\delta_{3}\right)$ & 3.429599 & 5.762464 & 0.595162 & 0.5517 \\
\hline N225 Volatiliy Spillover $\left(\delta_{4}\right)$ & 2.592755 & 5.147576 & 0.503685 & 0.6145 \\
\hline R-squared & 0.299885 & \multicolumn{2}{|c|}{ Mean dependent var } & $-6.79 \mathrm{E}-05$ \\
\hline Adjusted R-squared & 0.288945 & \multicolumn{2}{|c|}{ S.D. dependent var } & 0.016302 \\
\hline S.E. of regression & 0.013746 & \multicolumn{2}{|c|}{ Akaike info criterion } & -6.162320 \\
\hline Sum squared resid & 0.048375 & \multicolumn{2}{|c|}{ Schwarz criterion } & -5.984777 \\
\hline Log-likelihood & 817.1828 & \multicolumn{2}{|c|}{ Hannan-Quinn criter. } & -6.090954 \\
\hline Durbin-Watson stat & 1.926308 & & & \\
\hline
\end{tabular}

Note: Significance at a $10 \%$

At a significance of $10 \%$, it shows that the parameters $\delta_{1}, \delta_{2}, \delta_{3}$, and $\delta_{4}$ have p-value > a $10 \%$, namely: $0.2979,0.1589,0.5517$, and 0.6145 respectively, so it can be proven that the shock or volatility occurs in China's stock markets, Singapore, South Korea, and Japan have no significant impact on the Indonesian stock market.

The result of parameter Asymmetry Coefficient $(\gamma)$ is -0.167792 with a p-value of $0.0004<\alpha 10 \%$, indicating that the Asymmetry Coefficient $(\gamma)$ is negative and significant, which means there is an asymmetric effect. So the impact of bad news in China, Singapore, South Korea, and Japan has a more significant impact than good news. 
Table 5. ARCH Effect Test: LM-Test

\begin{tabular}{llll}
\hline F-statistic & 0.193891 & Prob. F(1,62) & 0.6601 \\
Obs*R-squared & 0.195248 & Prob. Chi-Square(1) & 0.6586 \\
\hline
\end{tabular}

Note: Significance at a $10 \%$

Based on table 5, it can be seen that the ARCH LM-Test above shows the value Prob. obs- $\mathrm{R}^{*}$-squared is 0.6586 , so it is proven that the $\mathrm{p}$-value $>$ a $10 \%$. So, it can be stated that the model used has produced residues that do not have heteroscedasticity symptoms. This means that the characteristics volatility clustering in the research data has been accommodated from the EGARCH model.

\section{DISCUSSION}

Parameter $\delta 1$, namely the Shanghai Composite Index (SSEC) variable, does not affect JKSE. The probability value evidences the research results. SSEC is $0.2979>$ a $10 \%$, indicating no spillover volatility from the Chinese stock market to the Indonesian stock market. So that the hypothesis is null accepted $\left(\delta_{1}=0\right)$, then there is no spillover volatility at a $10 \%$ of the Chinese stock market against the Indonesian stock market. The results of this study have differed from research conducted by Martin and Yunita (2010). They found a unidirectional relationship with the spillover volatility from the Chinese stock market to the Indonesian stock market. However, this study is the same as research conducted by Kibtiyah, Shintia, and Trikartika (2017), who found that the high economic relationship between China and Indonesia does not mean that shocks or volatility in the Chinese stock market do not always cause shocks. This shock is an example of the volatility in the Indonesian stock market, especially during the Covid-19 pandemic in 2020.

Parameter $\delta 2$, namely the Strait Times Index (STI) variable, has no impact on JKSE. The probability value evidences the research results. STI is $0.1589>$ a $10 \%$, indicating no spillover volatility from the Singapore stock market to the Indonesian stock market. So that the hypothesis is null accepted $\left(\delta_{2}=0\right)$, then there is no significant spillover volatility at $\alpha$ $10 \%$ of the Singapore stock market against the Indonesian stock market. All the theoretical literature that has been presented in the previous chapter show does not match with this research, that there is a close relationship between Singapore and Indonesia which causes the turmoil that occurs in the Singapore stock market, which can affect the volatility of the return on the Indonesian stock market. (Panjaitan and Saadah, 2018; Saadah, 2013; Lestano and Sucito, 2010; Sari, Achsani, and Sartono, 2017).

Parameter $\delta 3$, namely the Korean Composite Index (KS11) variable, has no significant effect on JKSE. The probability value evidences the research results. KS11 is $0.5517>$ a $10 \%$, indicating no spillover volatility from the South Korean stock market to the Indonesian stock market. So that the hypothesis null fails to be rejected $\left(\delta_{3}=0\right)$, then there is no significant spillover volatility at a $10 \%$ of the South Korean stock market against the Indonesian stock market. In accordance with research from $\mathrm{Wu}$ (2005), who found that South Korea has no significant effect on the spillover volatility to the Indonesian stock market.

Parameter 84 , namely the Nikkei 225 (N225) variable, has no significant effect on JKSE. The probability value evidences the research results. N225 is $0.6145>$ a $10 \%$, indicating no spillover volatility from the Japanese stock market to the Indonesian stock market. So that the hypothesis null fails to be rejected $\left(\delta_{4}=0\right)$, then there is no significant spillover volatility at a $10 \%$ of the Japanese stock market against the Indonesian stock 
market. The results of this study are not in line with Miyakohsi's (2003) research, where the Japanese stock market influences the volatility of the Asian stock market (there is Indonesia).

Response asymmetry in spillover volatility can be seen in table 3., as reflected through the Asymmetry Coefficient $(\gamma)$ of -0.167792 with a p-value $0.0004<\alpha 10 \%$, showing results significant response to asymmetry spillover volatility that happened in China, Singapore, South Korea, Japan, and Indonesia Stock. When a negative shock occurs on the stock markets of China, Singapore, South Korea, Japan, and Indonesia, it will have a much more significant impact than those stock markets that are in a state of return positive. The existence of pattern asymmetric in this research model means that the stock market under study shows the characteristics of the leverage effect $(\gamma<0)$, where the increased volatility is greater after the trend downward in prices than the trend of increasing prices. This is in line with research from Black (1976) and Christie (1982), which shows that there is a significant relationship between volatility equity and financial leverage, which causes volatility to equity increase with leverage; however, this increase occurs when it decreases (shock negative).

There are several factors behind the absence of the spillover effect of volatility from China, Singapore, South Korea, and Japan on the Indonesian stock market. First, there was an increase in share ownership by local investors. Qolbi (2020) states that based on capital market statistical data as of January 31, 2020, foreign investor ownership is still $52.48 \%$, while local investors are $47.52 \%$ of the total shares of IDR 3.505 trillion. However, on October 2, 2020, released by the Financial Services Authority (OJK), local investors' share ownership reached $51.67 \%$ and foreign investors $48.33 \%$ of the total shares valued at IDR 3,055 trillion. The data above means that local investors dominate the movement of the Indonesian stock market. Second, there is a decrease in Indonesia's exports and imports in 2020. From the data published by the Ministry of Trade (Kemendag) of the State of Indonesia, there is a decrease in exports and imports where the export value in 2020 was US\$ $163,306.49$ million, down $-3 \%$ compared to 2019 , which amounts to US\$ 167,683.01. A decrease also followed the decline in exports in imports where the import value in 2020 was U.S. \$ $141,568.80$ million, a decrease of $-17 \%$ compared to 2019 , which amounted to US\$ 171,275.74. Third, there is no volatility spillover effect because each country is experiencing the same problem. Therefore, that market sentiment is more focused on how the government can prevent the increase in the number of positive Covid-19 cases and maintain the stability of the country's economy. If the government fails, then the stock market conditions will be unstable.

\section{CONCLUSIONS, LIMITATION, AND SUGGESTIONS}

Based on the above conclusions, the researcher can provide several recommendations, namely as follows: First, investors investing in the stock market are advised to deepen technical analysis, especially understanding of global market conditions. Investors who invest in the Indonesian stock market are advised to pay more attention to domestic economic conditions during the Covid-19 pandemic situation. Second, The Financial Services Authority (OJK) and Bank Indonesia (B.I.) are advised to make a quick response as a preventive measure to overcome any shock originating from local: Lastly, For future researchers, this research can be extended because the Covid19 pandemic has not ended, and many countries have confirmed that the covid-19 vaccination program will be carried out next year. The extension of the study period also helps better detect the presence 
of spillovers volatility. Then the addition of research variables can be added more from this research. Eventually, using dummy variables to see the impact of the spillover volatility before and after the covid-19 vaccination.

\section{REFERENCES}

Ang, A. \& Bekaert, G. (2002). International Asset Allocation with Regime Shifts. The Review of Financial Studies, 15(4), 1137-1187. https://doi.org/10.1093/rfs/15.4.1137

Black, F. (1976). Studies of Stock Price Volatility Changes: Proceedings of the 1976 Meetings of the Business and Economic Statistics Section. American Statistical Association,177191.

Bodie, Z, Kane, A., \& Marcus, A. (2017). Essentials Of Investments (10th ed). New York: McGraw-Hill Education.

Boone, L., Haugh, D., Pain, N., \& Salins, V. (2020). Tackling the fallout from COVID19. Economics in the Time of COVID-19, 37.

Brooks, C. (2008). Introductory Econometrics for Finance. New York: Cambridge University Press.

Campbell, J. Y., \& Hentschel, L. (1992). No news is Good News: An Asymmetric Model of Changing Volatility in Stock Returns. Journal of Financial Economics, 31(3), 281-318. https:// doi.org/10.1016/0304-405X(82)900186-6

Christie, A. A. (1982). The Stochastic Behavior of Common Stock Variances: Value, Leverage and Interest Rate Effects. Journal of financial Economics, 10(4), 407-432. https:// doi.org/10.1016/0304-405X(92)90037-X

Das, S. R., \& Uppal, R. (2004). Systemic Risk and International Portfolio Choice. The Journal of Finance, 59(6), 2809-2834. https://doi.org/10.1111/j.1540-6261.2004.00717.x

Drazen, A. (1998). Political Contagion in Currency Crisis. NBER Working Paper, 7211. https://www.nber.org/papers/w7211

Hill, R. C., Griffiths, W. E., \& Lim, G. C. (2012). Principles of Econometrics (4th ed.). Hoboken, New Jersey.

Huang, C., et ell. (2020). Clinical Features of Patients Infected With 2019 Novel Coronavirus in Wuhan, China. Lancet 2020; 395: 497-506. https://doi.org/10.1016/S01406736(20)30183-5

Hull, J. (2012). Risk Management and Financial Institutions, Web Site (Vol. 733). John Wiley \& Sons.

Jebran, K., Chen, S., Ullah, I., \& Mirza, S. S. (2017). Does volatility spillover among stock markets varies from normal to turbulent periods? Evidence from emerging markets of Asia. The Journal of Finance and Data Science, 3(1-4), 20-30. https:// doi.org/10.1016/j.jfds.2017.06.001 
Joshi, P. (2011). Return and volatility spillovers among Asian stock markets. Sage Open, 1(1), 2158244011413474. https://doi.org/10.1177/2158244011413474

Khan, K., ZHAO, H., Zhang, H., Yang, H., Shah, M. H., \& Jahanger, A. (2020). The impact of COVID-19 pandemic on stock markets: An empirical analysis of world major stock indices. The Journal of Asian Finance, Economics, and Business, 7(7), 463474.https:// doi.org/10.13106/jafeb.2020.vol7.no7.463

Kibtiyah, M., Shintia Dewi, A., \& Trikartika Gustyana, T. (2017). Analisis Spillover Volatilitas Pasar Saham Indonesia dan China. Majalah Ilmiah UNIKOM, 15. https://jurnal.unikom.ac.id/jurnal/analisis-spillover.61

Koutmos, G. (1998). Asymmetries in The Conditional Mean And The Conditional Variance: Evidence from Nine Stock Markets. Journal of Economic and Business, 50(3), 277-290. https:// doi.org/10.1016/S0148-6195(98)00004-6

Koutmos, G. \& Booth, G. (1995). Asymmetries Volatility Transmission In International Stock Markets. Journal of International Money and Finance, 14(6), 747-762. https:/ / doi.org/10.1016/0261-5606(95)00031-3

Lestano, L., \& Sucito, J. (2010). Spillover Volatilitas Pasar Saham Indonesia dan Singapura periode 2001-2005. Jurnal Akuntansi dan Keuangan, 12(1), 17-25. https://doi.org/10.9744/jak.12.1.pp.\%2017-25

Lin, W. L., Engle, R. F., \& Ito, T. (1994). Do Bulls and Bears Move Across Borders? International Transmission of Stock Returns and Volatility. Review of financial studies, 7(3), 507-538. https://doi.org/10.1093/rfs/7.3.507

Martin, M., \& Yunita, Y. (2010). Volatility Spillover pada Pasar Saham Indonesia, Cina, dan India. Binus Business Review, 1(1), 40-49. https:/ / doi.org/10.21512/bbr.v1i1.1020

Masson, P. (1997). Monsoonal Effects, Spillovers, and Contagion. Mimeograph, International Monetary Fund.

Masson, P. (1998). Contagion: Monsoonal Effects, Spillovers, and Jumps Between Multiple Equilibria. International Monetary Fund, Working Paper, 98/142, September.

Miyakohsi, T. (2003). Spillover of Stock Return Volatility to Asian Equity Market from Japan, USA. Journal of International Finance Market, Institutions and Money, 13(4), 383399. http:// doi.org/10.1016/S1042-4431(03)00015-5

Mullainathan, S. (2002). A Memory-based Model Of Bounded Rationality. The Quarterly Journal of Economics, 117(3), 735-774. https:/ / doi.org/10.1162/003355302760193887

Nam, K., Pyun, C.S., \& Avard, S.L. (2001). Asymmetric Reverting Behavior of Short Horizon Stock Returns: An Evidence of Stock Market Overreaction. Journal of Banking and Finance, 25(4), 807-824. https:// doi.org/10.1016/S0378-4266(00)00110-2

Nelson, D. B. (1991). Conditional Heteroskedasticity In Asset Returns: A New Approach. Econometrica: Journal of the Econometric Society, 347-370. https:// doi.org/10.2307/2938260 
Panjaitan, Y., \& Saadah, S. (2018). Volatility Spillover Analysis Post Implementation of AEC 2015 Agreement: Empirical Study on ASEAN-5 Stock Market. International Journal of Financial Research, 9(2), 105-111. https://doi.org/10.5430/ijfr.v9n2p105

Qolbi, N. (2020, November 02). Kepemilikan Investor Domestik Mendominasi Pasar Saham, Daya Tahan IHSG Lebih Kokoh. Investasi.kontan.co.id, March 08, 2021. https://investasi.kontan.co.id/news/kepemilikan-investor-domestikmendominasi-pasar-saham-daya-tahan-ihsg-lebih-kokoh

Saadah, S. (2013). Response Asymmetry in Spillover Volatility: An Empirical Study in the Indonesia and Singapore Stock Market. Indonesian Capital Market Review, 5(2). https:// doi/org/10.21002/icmr.v5i2.1898

Sari, L. K., Achsani, N. A., \& Sartono, B. (2017). The Volatility Transmission of Main Global Stock's Return to Indonesia. Buletin Ekonomi Moneter dan Perbankan, 20(2), 229-256. https:// doi.org/10.21098/bemp.v20i2.813

Sharma, S. S. (2020). A note on the Asian market volatility during the COVID-19 pandemic. Asian Economics Letters, 1(2), 17661. https://doi.org/10.46557/001c.17661

Tumbelaka, Indra. (2019). On Volatility Spillover in the Emerging Stock Market: Asymmetric Model for Indonesia. OJK Working Paper, WP/19/01, December.

Valdés, R. (1996). Emerging Market contagion: Evidence and Theory. MIT Mimeo.

Winarno, Wing Wahyu. (2015). Analisis Ekonometrika dan Statistika dengan EViews (edisi 4). UPP STIM YKPN: Yogyakarta.

Wren-Lewis, S. (2020). Tackling the fallout from COVID-19. Economics in the Time of COVID19, 109. https://voxeu.org/ content/ economics-time-covid-19

Wu, R.S. (2005). International Transmission Effect Of Volatility Between The Financial Markets During The Asian Financial Crisis. Transition Studies Review, 12(1), 19-35. https:// doi.org/10.1007/S11300-005-0032-5 